\title{
Use of autogenous bone graft of the anterior wall of the maxillary sinus in the management of oroantral fistula
}

\author{
Uso de enxerto ósseo autógeno da parede anterior do seio maxilar no manejo da fístula oroantral \\ Uso de injerto óseo autógeno de la pared anterior del seno maxilar en el manejo de la fístula oroantral \\ José Cadmo Wanderley Peregrino de ARAÚJO-FILHO \\ José Murilo BERNARDO-NETO ${ }^{2}$ \\ Júlio Leite de ARAÚJO JÚNIOR \\ Eduardo DIAS-RIBEIRO ${ }^{4}$ \\ Julierme Ferreira ROCHA ${ }^{5}$ \\ ${ }^{1}$ Professor da disciplina de Cirurgia Bucal da Universidade Federal de Campina Grande, 58431-100, Campina Gande, PB, Brasil \\ ${ }^{2}$ Residente em Cirurgia e Traumatologia Bucomaxilofacial pela UFPB - Universidade Federal da Paraíba, 58011-298, João Pessoa - PB, Brasil \\ ${ }^{3}$ Residente em Cirurgia e Traumatologia Bucomaxilofacial pela UFPB - Universidade Federal da Paraíba, 58051-790, João Pessoa - PB, Brasil \\ ${ }^{4}$ Professor do Programa de Residência em Cirurgia e Traumatologia Bucomaxilofacial da UFPB - Universidade Federal da Paraíba, 58052-290 João Pessoa - PB, Brasil \\ ${ }^{5}$ Professor da disciplina de Cirurgia Bucal da Universidade Federal de Campina Grande, 58417-598, Campina Gande - PB, Brasil
}

\begin{abstract}
Introduction: The oroantral fistula consists of a persistent communication between the maxillary sinus and the buccal cavity, being a complication resulting from traumas, pathologies or dental extractions. Objective: To present a clinical case of oroantral fistula closure using autogenous bone graft from the anterior sinus wall as a treatment option. Materials and Methods: Patient with a history of traumatic extraction of the upper left molars about 4 months ago. During the clinical examination, there was an orifice in the left maxillary alveolar crest, suggestive of oroantral fistula, responding positively to the Valsalva maneuver. Panoramic radiographic examination evidenced continuity between the oral cavity and the left maxillary sinus, which presented with opacification, suggestive of acute maxillary sinusitis on the left side. Sinusitis was treated within 15 days. After treatment, we evaluated the patient who was asymptomatic and, at that moment, the surgical procedure for the oroantral fistula closure was planned, removing a bone block from the anterior wall of the left maxillary sinus presenting the sinus membrane and grafting with fixation using System $1.5 \mathrm{~mm}$ with an "L" plate and four bolts. Conclusion: This surgical technique is useful for the closure of chronic oroantral fistulas in patients with oroantral fistulas.
\end{abstract}

Descriptors: Oroantral Fistula; Bone Transplantation; Maxillary Sinus.

\section{Resumo}

Introdução: A fístula oroantral consiste em uma comunicação persistente entre o seio maxilar e a cavidade bucal, sendo uma complicação resultante de traumas, patologias ou extrações dentárias. Objetivo: Apresentar um caso clínico de fechamento de fistula oroantral utilizando o enxerto ósseo autógeno da parede do seio anterior como opção de tratamento. Materiais e Métodos: Paciente com histórico de extração traumática dos molares superiores esquerdo há cerca de 4 meses. Durante o exame clínico, verificou-se um orifício na crista alveolar maxilar esquerda, sugestivo de fistula oroantral, respondendo positivamente à manobra de Valsalva. Ao exame radiográfico panorâmica evidenciou continuidade entre a cavidade oral e o seio maxilar esquerdo, que se apresentou com opacificação, sugestiva de sinusite maxilar aguda do lado esquerdo. A sinusite foi tratada em 15 dias. Após o tratamento, avaliamos o paciente que estava assintomático e, nesse momento, o procedimento cirúrgico para o fechamento da fistula oroantral foi planejado, removendo um bloco ósseo da parede anterior do seio maxilar esquerdo presenvando a membrane sinusal e enxertando com fixação utilizando o Sistema $1.5 \mathrm{~mm}$ com uma placa em "L" e quarto parafusos. Conclusão: Esta técnica cirúrgica é útil para fechamento de fístulas oroantrais crônicas em pacientes com fístulas oroantrais.

Descritores: Fístula Bucoantral; Transplante Ósseo; Seio Maxilar.

\section{Resumen}

Introducción: La fístula oroantral consiste en una comunicación persistente entre el seno maxilar y la cavidad bucal, siendo una complicación resultante de traumas, patologías o extracciones dentales. Objetivo: Presentar un caso clínico de cierre de fistula oroantral utilizando el injerto óseo autógeno de la pared del seno anterior como opción de tratamiento. Material y Métodos: Paciente con historia de extracción traumática de los molares superiores izquierdo hace cerca de 4 meses. Durante el examen clínico, se verificó un orificio en la cresta alveolar maxilar izquierda, sugestivo de fistula oroantral, respondiendo positivamente a la maniobra de Valsalva. En el examen radiográfico panorámico evidenció continuidad entre la cavidad oral y el seno maxilar izquierdo, que se presentó con opacificación, sugestiva de sinusitis maxilar aguda del lado izquierdo. La sinusitis fue tratada en 15 días. Después del tratamiento, evaluamos al paciente que estaba asintomático y, en ese momento, el procedimiento quirúrgico para el cierre de la fistula oroantral fue planeado, removiendo un bloque óseo de la pared anterior del seno maxilar izquierdo previniendo la membrana sinusal e injertando con fijación utilizando el Sistema $1.5 \mathrm{~mm}$ con una placa en "L" y cuarto tornillos. Conclusión: Esta técnica quirúrgica es útil para el cierre de fístulas doradas crónicas en pacientes con fístulas doradas. Descriptores: Fístula Oroantral; Trasplante Óseo; Seno Maxilar.

\section{INTRODUCTION}

The oroantral communication may be defined as a break in continuity between the maxillary sinus and the oral cavity. As for the trajectory it is covered by epithelium, due to failures in the process of bone repair, the OAF definition is more adequate. The most common etiological factors are: extractions, resection of cysts and tumors, trauma and infection ${ }^{1}$.

The use of local flaps (palatine, buccal), distant flaps (tongue, temporal), combination of the techniques, pedicled buccal fat pad graft and bone grafts are the most used surgical techniques for the closing of the OAF. There is no report in literature of the use of the anterior wall of the maxillary sinus for this purpose ${ }^{2}$.
We describe the use of the autogenous bone graft of the anterior wall of the maxillary sinus technique for the closing of the OAF.

\section{CLÍNICAL CASE}

A 41-year-old woman presented to the Faculty of Dentistry of the Federal University of Campina Grande, Patos, Brazil, complaining of moderate pain in the middle third of the left hemiface and discharge of fluid through the nostril during meals. The patient accepted to participate in the study and signed the consent form.

During the anamnesis, the patient reported a traumatic extraction of the upper molars on the left 
side about 4 months ago. During the clinical examination, there was a crest hole of the left maxillary alveolar ridge, suggestive of oroantral fistula, responding positively to the Valsalva maneuver. No systemic impairment.

We requested a panoramic radiograph showing a break in continuity between the oral cavity and the left maxillary sinus (Figure 1), which presented with opacification, suggestive of acute maxillary sinusitis on the left side. Sinusitis was treated within 15 days. After treatment, we evaluated the patient who was asymptomatic and, at that moment, the surgical procedure for the closure of the oroantral fistula was planned.

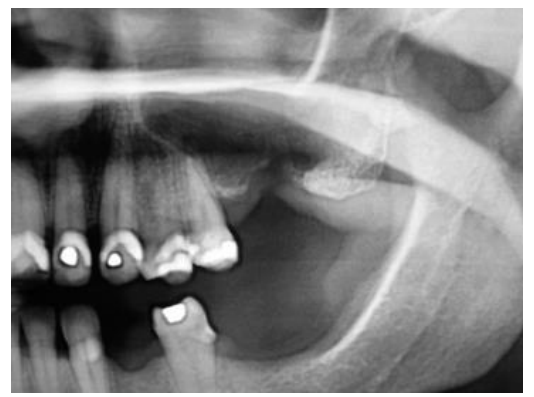

Figure 1: Preoperative panoramic radiograph evidencing the bone defect between the nasal cavity and oral cavity.

\section{- Operating Technique}

We performed a flap on the bony crest and maxillary tubercle to the defect region, where a anterior relaxing incision, exposing the fistula area and the anterior wall of the maxillary sinus. After exposure of the defect, a fistulectomy was performed. The bone defect was $8 \mathrm{~mm}$ in size. The bone graft compatible with the defect was removed by a handpiece attached to a No. 6 carbide surgical drill and abundant irrigation with $0.9 \%$ saline solution (Figure 2).

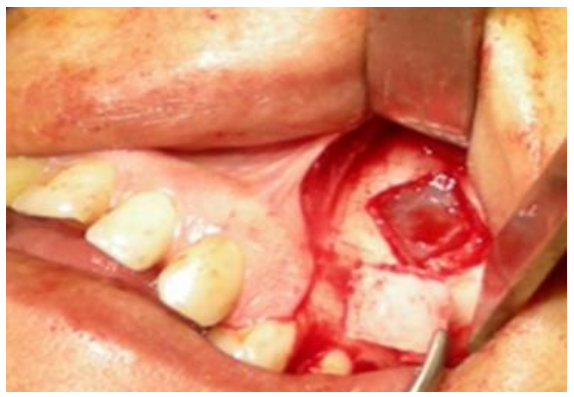

Figure 2: Aspect of the donor area after removal of the block.

The integrity of the maxillary sinus membrane was maintained. For complete removal of the graft, Wagner's curved chisel was used. The bone graft was stabilized in the defect area by the titanium plate with four $5 \mathrm{~mm}$ screws (Engimplan $\odot$ ) $1.5 \mathrm{~mm}$ system, Rio Claro-SP, Brazil) (Figure 3). The suture with simple stitches was performed with absorbable thread. The sutures were removed postoperatively for 10 days and the patient did not present eventualities.

The patient was followed up for 4 months in which she remained asymptomatic, when then the need arose for the removal of the fixation plate (Figure 4), aiming at prosthetic rehabilitation by means of a removable partial denture. During the procedure to remove the plaque, the complete incorporation of the graft was detected and complete closure of the communication. Five years after the procedure, the patient is in clinical and radiographic follow-up, remaining without clinical complaints (Figure 5).

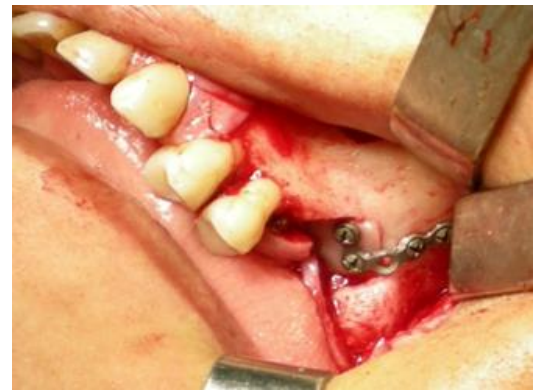

Figure 3: Fixation of the donor block in the receiving area with titanium plate and screws.

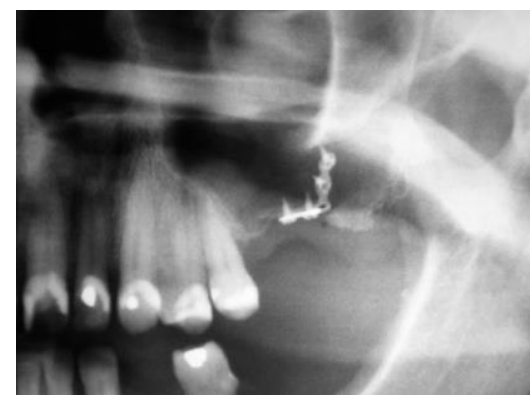

Figure 4: Immediate postoperative radiograph evidencing the fixation with plate and screws in the bone block.

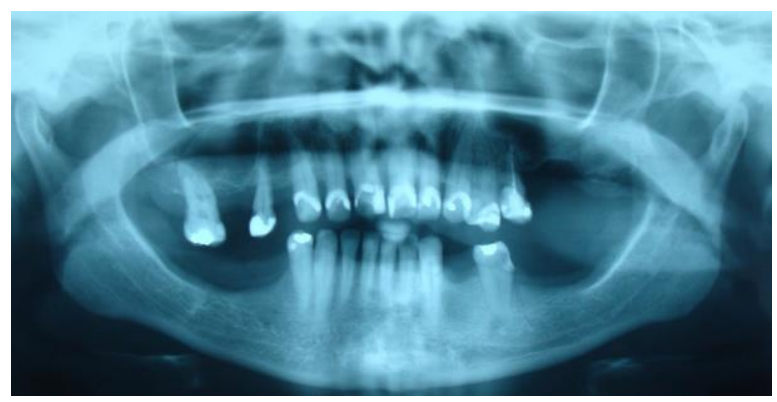

Figure 5: Postoperative radiography after 5 years.

DISCUSSION

To date, various methods of treatment have been introduced in the management of sinus buco communications. The most common and most used method has been the buccal flap technique. Oral and maxillofacial surgeons consider this method as reliable, effective and predictive. However, there were some disadvantages of this method, such as decreased vestibular groove depth, postoperative pain and edema ${ }^{3}$.

The studies of Hass et al. $^{4}$ used a monocortical bone graft in the treatment of buco sinusal communications. The autogenous graft, which is collected with trephine drill, is adapted in the defect area. In this technique, the plate screws are used if necessary. Although the donor area morbidity 
and the sensitivity of the intervention are the drawbacks of this method, another manual filling of the area of the defect with autogenous bone graft provides an advantage over the implant surgery in the future ${ }^{4}$. Already in the studies of Zide et $\mathrm{al}^{5}$. used the hydroxyapatite blocks in the treatment of oroantral communications after adapting them to the defect ${ }^{4}$.

In the literature, there are also studies reporting on the repair of large oroantral communications with a collagen membrane. In the present case no membrane was used ${ }^{6}$.

For internal grafting of the maxilla, the sinus membrane must be intact without signs of inflammation. In the present case the sinusitis was treated previously. Chronic oroantral fistulas generally cause chronic inflammatory thickening of the sinus membrane and therefore dictate that the breast lift not be used ${ }^{7}$.

Soft tissue closure of oroantral fistulas has a high risk of lesion of the nasal mucosa in future implant procedures because of the adhesion of the oral mucosa to the Schneiderian membrane ${ }^{8,9}$.

Closure of oroantral fistulas with bone grafts removed from the iliac crest, reported in 1969 by Proctor ${ }^{9}$, is an attractive option, but its use should be reserved for major defects due to the inherent morbidities of this procedure 9 .

A congruent adjustment of the defect graft is the key for bone healing, this can be ensured with correspondingly sized drills. Bone harvesting in intraoral donor sites substantially reduced postoperative patient morbidities ${ }^{4.11,12}$.

\section{CONCLUSION}

It is concluded that this surgical technique is useful for closing chronic oroantral fistulas, aiming at conventional sinus removal and rehabilitation with dental implants, thus closing oroantral communications that extend along exposed root surfaces.

\section{REFERENCES}

1. Martín-Granizo R, Naval L, Costas A, Goizueta C, Rodriguez F, Monje F, Muñoz M, Diaz F. Use of buccal fat pad to repair intraoral defects: review of 30 cases. $\mathrm{Br} \mathrm{J}$ Oral Maxillofac Surg. 1997;35(2):81-4.

2. Yilmaz T, Suslu AE, Gursel B. Treatment of oroantral fistula:experience with 27 cases. Am J Otolaryngol. 2003;24(4):221-23.

3. Anavi Y, Gal G, Silfen R, Calderon S. Palatal rotation-advancement flap for delayed repair of oroantral fistula: a retrospective evaluation of 63 cases. Oral Surg Oral Med Oral Pathol Oral Radiol Endod. 2003;96(5):527-34.

4. Haas R, Watzak G, Baron M. A preliminary study of monocortical bone grafts for oroantral fistula closure. Oral Surg Oral Med Oral Pathol Oral Radiol Endod. 2003;96(3):263-66
5. Zide MF, Karas ND. Hydroxylapatite block closure of oroantral fistulas: report of cases. J Oral Maxillofac Surg. 1992;50(1):71-5.

6. Poeschl PW, Baumann A, Russmueller G, Poeschl E, Klug C, Ewers R. Closure of oroantral communications with Bichat's buccal fat pad. J Oral Maxillofac Surg. 2009;67(7):1460-6.

7. Jain MK, Ramesh C, Sankar K, Lokesh Babu KT. Pedicled buccal fat pad in the management of oroantral fistula: a clinical study of 15 cases. Int J Oral Maxillofac Surg. 2012;41(8):1025-29.

8. Amaratunga NA. Oro-antral fistulae--a study of clinical, radiological and treatment aspects. $\mathrm{Br} \mathbf{J}$ Oral Maxillofac Surg. 1986;24(6):433-37.

9. Proctor B. Bone graft closure of large or persistent oromaxillary fistula. Laryngoscope 1969;79(5):822-26.

10. Visscher SH, van Minnen B, Bos RR. Closure of oroantral communications: a review of the literature. J Oral Maxillofac Surg. 2010;68(6):1384-91.

11.Visscher SH, van Roon MR, Sluiter WJ, van Minnen B, Bos RR. Retrospective study on the treatment outcome of surgical closure of oroantral communications. J Oral Maxillofac Surg. 2011;69(12):2956-61.

12.Hanazawa Y, Itoh K, Mabashi T, Sato K. Closure of oroantral communications using a pedicled buccal fat pad graft. J Oral Maxillofac Surg. 1995;53(7):771-75.

\section{CONFLICTS OF INTERESTS}

The authors declare no conflicts of interests.

\section{CORRESPONDING AUTHOR}

\section{Júlio Leite de Araújo Júnior}

juniorleitearaujo@hotmail.com 